\title{
Factors Affecting the Quality of Diagnosis Coding and Medical Record at Dr. Moewardi Hospital, Surakarta
}

\author{
Warsi Maryati'), Bhisma Murti²), Dono Indarto3) \\ 1)School of Medical Records, APIKES Citra Medika, Surakarta \\ ${ }^{2)}$ Masters Program in Public Health, Universitas Sebelas Maret \\ 3)Faculty of Medicine, Universitas Sebelas Maret
}

\begin{abstract}
Background: Diagnosis coding is atool for identifying and grouping diseases, disorders, symptoms, and other disease-related outcomes, such as poisoning, adverse effect of drugs and chemicals, and injury. Diagnosis code can be used in policy making and costing medical care. Doctors, nurses, coding personnel, and medical record quality, may affect the quality of diagnosis coding. This study aimed to investigate factors that affectsthe quality of diagnosis coding at Dr. Moewardi Hospital, Surakarta.

Subjects and Method: This was an analytic observational using cross sectional design. This study was conducted at Dr. Moewardi Hospital, Surakarta, Indonesia. A total of 250 inpatient medical record document at Dr. Moewardi Hospital were selected for the study bystratified random sampling.The data was analyzed by structural equation modeling (SEM).

Results: Sub-specialistic doctor $(b=1.13 ; 95 \% \mathrm{CI}=0.06$ to $0.33 ; \mathrm{p}=0.039)$, civil servant doctor $(\mathrm{b}=$ $0.84 ; 95 \% \mathrm{CI}=0.06$ to $1.62 ; \mathrm{p}=0.034)$, nurse tenure $\geq 5$ years $(\mathrm{b}=1.77 ; 95 \% \mathrm{CI}=1.13$ to $2.42 ; \mathrm{p}$ $<0.001)$, increased the quality of medical record. Health personnel aged $\geq 40$ years $(b=1.70 ; 95 \%$ $\mathrm{CI}=0.64$ to $2.77 ; \mathrm{p}=0.002)$, tenure $\geq 5$ years $(\mathrm{b}=1.70 ; 95 \% \mathrm{CI}=0.98$ to $2.42 ; \mathrm{p}=0.001)$, and personnel has $\geq 5$ times training $(b=2.62 ; 95 \% \mathrm{CI}=1.40$ to $3.83 ; \mathrm{p}<0.001)$, increased the quality of diagnosis coding.

Conclusion: Sub-specialistic doctor, civil servant doctor, tenure $\geq 5$ years, increased the quality of medical record. Health personnel aged $\geq 40$ years, tenure $\geq 5$ years, and personnel has $\geq 5$ times training, increased the quality of diagnosis coding.
\end{abstract}

Keywords: Quality of diagnosis coding, quality of medical record, doctor, nurse, coding personnel

Correspondence:

Warsi Maryati. School of Medical Records and Health, APIKES Citra Medika, Surakarta. Email: warsi_maryati@yahoo.com

\section{BACKGROUND}

$\overline{\text { Diagnosis coding has a very important role }}$ for health care providers as a basis for making statistics for trends in disease. Diagnosis coding is also the basis for determining the cost of health services. Diagnosis coding that is not qualified will cause harm to hospitals in financial and policy-making (WHO, 2010).

Factors that can affect the quality of the diagnosis code among doctors, other medical personnel (nurses), and medical record staff (coding personnel). Doctors and nurses are responsible for the quality of the patient's medical record documents and the coding personnelsare responsible for the quality of the diagnosis code based on the medical data (Ministry of Health, 2006).

Individual characteristics are internal (interpersonal) factors that move and influence individual behavior (Hurriyati, 2005). Characteristics of individuals who can influence performance are age, tenure, education, training, and employment status (Suma'mur, 2014). 
Journal of Health Policy and Management (2016), 1(2): 61-71

https://doi.org/10.26911/thejhpm.2016.01.02.01

The diagnosis coding in a public hospital is significantly more appropriate than in special hospital. However, there are more numbers of diagnosis coding with types of major errors in public hospitals (Farzandipouret al., 2010). Dr. Moewardi hospital is a public hospital that has type A Education and has 232 doctors, 721 nurses, and 16 coding personnels of inpatient's medical record documents.

From the results of preliminarystudy, $40 \%$ of the 10 medical record documents of inpatients have poor quality diagnostic codes. Sudra and Pujihastuti (2016) also showed that the percentage of the inaccuracy of the diagnosis coding in Dr. Moewardi Hospital as many as $34.2 \%$ of 380 medical record documents. Theinaccuracy percentage of the diagnosis coding is higher than the average of other domestic hospitals, which is $31.5 \%$ (Arifianto et al., 2011; Rahayu et al., 2011; Rohman et al., 2011; Abiyasa et al., 2012; Ifalahma, 2013; Sarwastutik, 2013; Pujihastuti and Sudra, 2014; Seruni and Sugiarsi, 2015; Karimah et al., 2016) and still very much higher compared to overseas hospitals by $12.71 \%$ (Farzandipouret al., 2010; Cheng et al., 2009; Dalal and Roy, 2009; Thigpen et al., 2015; Cummings et al., 2011).

This study aimed to investigate factors that affectsthe quality of diagnosis coding at Dr. Moewardi Hospital, Surakarta.

\footnotetext{
SUBJECTS AND METHOD

The type of the study was observational analytic study with cross sectional design. The study population was all inpatient medical record documents at Dr. Moewardi hospital, Surakarta in October - November 2016. The number of samples in the study was 250 medical record documents in the Orchid, Melati, Mawar, Cendana and Aster wards which were selected by stratified ran-
}

dom sampling with 50 documents for each ward.

Data was collected using observation tables, medical analysis document quality sheet, analysis sheet accuracy, consistency, completeness and timeliness of diagnosis codes, ICD-10, and stopwach. Data were analyzed by univariate, bivariate with chisquare, and multivariate analysis with logistic regression using Structural Equation Modeling in Stata 13.

\section{RESULT}

The subjects of this study included 64 doctors, 276 nurses, and 16 coders in Dr. Moewardi hospital, Surakarta. Table 1 shows the majority of doctors aged $\geq 40$ years by $68.80 \%$, the working period of doctors $\geq 5$ years by $71.90 \%$, doctors who possessed doctoral degree as many as $57.80 \%$, subspecialty doctors as many as $56.30 \%$ and civil servant doctors as many as $92.2 \%$.

Table 2 shows that most of the nurses $<40$ years were $87.70 \%$, nurses' working period $<5$ years were $56.50 \%$, nurses who possessed associate's degree were $73.90 \%$ and civil servant nurses were $60.10 \%$.

Table 3 shows that most coding personnels were $<40$ years old $(87.50 \%)$, working period of coding personnels $<5$ years as many as $62.50 \%$, coding personnels who possessed associate's degree were $93.80 \%$, coding personnels with the number of training $<5$ times as many as $87.50 \%$ and non civil servant coding personnels as many as $56.20 \%$.

Most medical record documents hada good quality, as many as $164(65.60 \%)$, the quality of medical records that was not good as many as $86(34.40 \%)$. The quality of the diagnosis coding was mostly good, as many as 152 (60.80\%). While, the diagnosis coding that was not good were 98 (39.20\%).

Table 4 shows the results of path analysis with the selection of Generalized 
Structural Equity Modeling (GSEM) in Stata 13. Age of the coding personnel $\geq 40$ years had logodds 1.70 better in the quality of diagnosis coding than age $<40$ years $(b=$ $1.70 ; 95 \% \mathrm{CI}=0.64$ to $2.77 ; \mathrm{p}=0.002$ ).

Table 1.The characteristics of doctors

\begin{tabular}{llcc}
\hline \multicolumn{1}{c}{ Variable } & \multicolumn{1}{c}{ Category } & N & \% \\
\hline Age & < 40 years & 20 & 31.20 \\
Working period & $\geq$ 40 years & 44 & 68.80 \\
\multirow{2}{*}{ Education } & $<5$ years & 18 & 28.10 \\
& $\geq 5$ years & 46 & 71.90 \\
Type of expertise & Master degree & 27 & 42.20 \\
& Doctoral degree & 37 & 57.80 \\
Employment status & Specialist & 28 & 43.80 \\
& Sub-specialist & 36 & 56.30 \\
& Non Civil Servant & 5 & 7.80 \\
& Civil Servant & 59 & 92.20 \\
\hline
\end{tabular}

Table 2. The characteristics of nurses

\begin{tabular}{llcc}
\hline \multicolumn{1}{c}{ Variable } & \multicolumn{1}{c}{ Category } & N & \% \\
\hline Age & $<40$ years & 242 & 87.70 \\
Working period & $\geq 40$ years & 34 & 12.30 \\
\multirow{2}{*}{ Education } & $<5$ years & 156 & 56.50 \\
& $\geq 5$ years & 120 & 43.50 \\
Employment status & Associate's degree & 204 & 73.90 \\
& Bachelor & 72 & 26.10 \\
& Non Civil Servant & 110 & 39.90 \\
& Civil Servant & 166 & 60.10 \\
\hline
\end{tabular}

Table 3. The characteristics of coding personnel

\begin{tabular}{llcc}
\hline \multicolumn{1}{c}{ Variable } & \multicolumn{1}{c}{ Category } & $\mathbf{N}$ & \% \\
\hline Age & $<40$ years & 14 & 87.50 \\
Working period & $\geq 40$ years & 2 & 12.50 \\
& $<5$ years & 10 & 62.50 \\
Education & $\geq 5$ years & 6 & 37.50 \\
& Associate's degree & 15 & 93.80 \\
Training & Bachelor & 1 & 6.20 \\
& $<5$ times & 14 & 87.50 \\
Employment status & $\geq 5$ times & 2 & 12.50 \\
& Non Civil Servant & 9 & 56.20 \\
& Civil Servant & 7 & 43.80 \\
\hline
\end{tabular}

Bachelor-educated coding personnels had logodds 0.39 worse in the quality of the diagnosis coding than the coding personnel who possessed associate's degree, but not significant $(b=-0.39 ; 95 \% \mathrm{CI}=-1.91$ to 1.14 ; $\mathrm{p}=0.618)$. Coding personnel with training
Tenure $\geq 5$ years had logodds 1.70 better in the quality of diagnosis coding than tenure $<5$ years $(\mathrm{b}=1.70 ; 95 \% \mathrm{CI}=0.98$ to $2.42 ; \mathrm{p}$ $<0.001)$. 
Journal of Health Policy and Management (2016), 1(2): 61-71

https://doi.org/10.26911/thejhpm.2016.01.02.01

coding than non civil servant coding personnel, but not significant $(b=0.55 ; 95 \%$ $\mathrm{CI}=-0.18$ to $1.29 ; \mathrm{p}=0.141)$. The quality of a good medical record document had better logodds 1.54 in the quality of the diagnosis coding than the quality of the medical record document that was not good $(b=1.54$; $95 \% \mathrm{CI}=0.81$ to 2.27 ; $\mathrm{p}<0.001$ ).

Doctors who were $\geq 40$ years old had better logodds by 0.55 in the quality of medical record documents than who were $<40$ years, but not significant $(\mathrm{b}=0.55$; $95 \% \mathrm{CI}=$ - 0.14 to $1.24 ; \mathrm{p}=0.116$ ). Doctor tenure $\geq 5$ years had logodds by 0.32 better in the quality of medical record documents than tenure $<5$ years, but it was statistically non- significant $(\mathrm{b}=0.32 ; 95 \% \mathrm{CI}=-0.39$ to 1.03 ; $\mathrm{p}=0.375)$.

Doctors who had a doctoral degree education had a worse logodds of 0.05 in the quality of medical record documents than doctors who had magister degree education, but it was statistically non-significant $(b=-0.05 ; 95 \% \mathrm{CI}=-1.11$ to $1.00 ; \mathrm{p}=$ o.921). Sub-specialist doctors had better logodds of 1.13 in quality medical record documents than specialist doctors $(b=1.13$; $95 \% \mathrm{CI}=0.06$ to $2.21 ; \mathrm{p}=0.039$ ). Civil servant doctors had better logodds of 0.84 in the quality of medical record documents than doctors of non civil servants $(b=0.84$; $95 \% \mathrm{CI}=0.06$ to $1.62 ; \mathrm{p}=0.034$ ).

\section{Table 4. Factors that influence the quality of the diagnosis coding}

\begin{tabular}{|c|c|c|c|c|c|c|}
\hline \multirow[b]{2}{*}{$\begin{array}{l}\text { Dependent } \\
\text { Variable }\end{array}$} & \multirow[b]{2}{*}{ Independent Variable } & \multirow[b]{2}{*}{ b } & \multirow[b]{2}{*}{ SE } & \multicolumn{2}{|c|}{ CI (95\%) } & \multirow[b]{2}{*}{$\mathbf{p}$} \\
\hline & & & & $\begin{array}{l}\text { Lower } \\
\text { limit }\end{array}$ & $\begin{array}{l}\text { Upper } \\
\text { limit }\end{array}$ & \\
\hline \multirow{7}{*}{$\begin{array}{l}\text { Direct Effect } \\
\text { Quality of the } \\
\text { diagnosis code }\end{array}$} & & & & & & \\
\hline & $\leftarrow$ Age of coding personnel $\geq 40$ years & 1.70 & 0.54 & 0.64 & 2.77 & 0.002 \\
\hline & $\leftarrow$ Tenure of coding personnel $\geq 5$ years & 1.70 & 0.37 & 0.98 & 2.42 & $<0.001$ \\
\hline & $\begin{array}{l}\leftarrow \text { Education of coding personnel: } \\
\text { Bachelor }\end{array}$ & -0.39 & 0.78 & -1.91 & 1.14 & 0.618 \\
\hline & $\leftarrow$ Coding personnel's training $\geq 5$ times & 2.62 & 0.62 & 1.40 & 3.83 & $<0.001$ \\
\hline & $\begin{array}{l}\leftarrow \text { Employment status of the coding } \\
\text { personnel:civil servant }\end{array}$ & 0.55 & 0.37 & -0.18 & 1.29 & 0.141 \\
\hline & $\begin{array}{l}\leftarrow \text { Quality of medical record documents: } \\
\text { good }\end{array}$ & 1.54 & 0.37 & 0.81 & 2.27 & $<0.001$ \\
\hline \multicolumn{7}{|c|}{ Indirect Effect } \\
\hline \multirow{9}{*}{$\begin{array}{l}\text { Quality of the } \\
\text { medical record } \\
\text { documents }\end{array}$} & $\leftarrow$ Age of doctors $\geq 40$ years & 0.55 & 0.35 & -0.14 & 1.24 & 0.116 \\
\hline & $\leftarrow$ Doctor tenure $\geq 5$ years & 0.32 & 0.36 & -0.39 & 1.03 & 0.375 \\
\hline & $\leftarrow$ Education of doctor: doctoral degree & -0.05 & 0.54 & -1.11 & 1.00 & 0.921 \\
\hline & $\begin{array}{l}\leftarrow \text { Type of expertise of the doctor: Sub- } \\
\text { specialist }\end{array}$ & 1.13 & 0.55 & 0.06 & 2.21 & 0.039 \\
\hline & $\begin{array}{l}\leftarrow \text { Employment status doctor: civil } \\
\text { servant }\end{array}$ & 0.84 & 0.39 & 0.06 & 1.62 & 0.034 \\
\hline & $\leftarrow$ Age of nurses $\geq 40$ years & 0.22 & 0.35 & -0.47 & 0.91 & 0.532 \\
\hline & $\leftarrow$ Nurse tenure $\geq 5$ years & 1.77 & 0.33 & 1.13 & 2.42 & $<0.001$ \\
\hline & $\leftarrow$ Education of nurses:bachelor & 0.46 & 0.35 & -0.23 & 1.15 & 0.189 \\
\hline & $\begin{array}{l}\text { Employment status of nurses: civil } \\
\text { servant }\end{array}$ & -0.47 & 0.35 & -1.16 & 0.23 & 0.186 \\
\hline N Observation & 250 & & & & & \\
\hline Log likelihood & -221.16 & & & & & \\
\hline
\end{tabular}

The age of nurses $\geq 40$ years had logodds 0.22 units higher in the quality of medical record documents than nurses aged $<40$ years, but it was statistically non- significant $(\mathrm{b}=0.22$; CI95\% $=-0.47$ to 0.91 ; $\mathrm{p}=0.532$ ). Nurse tenure $\geq 5$ years have logodds 1.77 units higher in the quality of medical record documents than nurse 
tenure $<5$ years $(b=1.77 ; 95 \% \mathrm{CI}=1.13$ to 2.42; $\mathrm{p}<0.001)$. Nurses who have bachelor degree education had logodds 0.46 units higher in the quality of medical record documents than nurses with an associate's degree education, but it was statistically non-significant $(b=0.46 ; 95 \% \mathrm{CI}=-0.23$ to 1.15; $\mathrm{p}=0.189)$. Civil servant nurses had logodds 0.47 units lower in the quality of medical record documents than non civil servant nurses, but it was statistically nonsignificant $(b=-0.47 ; 95 \% \mathrm{CI}=-1.16$ to 0.23 ; $\mathrm{p}=0.186)$.

\section{DISCUSSION}

The results of this study indicated that the variables such as age, tenure, and medical education were related to the quality of medical record documents but were not statistically significant. This is because age, tenure, and medical education do not have a major influence on the performance of doctors. According to Lihawa et al., (2016), the magnitude of the effect of total work motivation variables through moderating individual characteristics (gender, age, and tenure) on physician performance variables was only $13.7 \%$, while the remaining was 82.3\% and was influenced by other variables. This study shows the characteristics of doctors that significantly influence the quality of the diagnosis coding through the quality of medical record documents, namely the type of expertise and employment status.

Sub-specialist doctors have better medical record document quality (80.20\%) than specialist doctors (49.60\%). A study by Yulianto and Santoso (2015), revealed that the higher the type of expertise possessed by the doctor, the better the doctor's perception of the medical services he receives. General practitioners perceive that the medical services they receive are not enough to meet their needs. Most general practitioners hope that there will be an increase in medical services that they receive in order to be able to finance their children's education to a higher level. In addition, specialists perceive that the medical services provided are in accordance with the workload and sufficient to meet their daily needs.

A study by Djafar et al., (2011), stated that the most influential management factor on specialist job satisfaction is the clarity of medical services. Muljani (2012), concluded that if the incentive program is perceived as fair and competitive by employees, the institution will find it easier to attract potential employees, maintain, and motivate employees to further improve their performance.

The quality of medical record documents from civil servant doctors (72.90\%) and non civil servant doctors $(63.40 \%)$ is not much different. However, it has a statistically significant influence. Other studies also state the same thing that there is a relationship between the type of staffing doctor and the completeness of writing medical record data on the patient's resume sheet (Sugiyanto, 2006). Some non civil servant doctors are doctors who work part time so that the doctor does not have much time in the hospital to complete the medical record document. In addition, giving incentives to doctors is one of the factors that can motivate the performance of doctors in completing medical record documents. Moreover, in the current implementation of JKN (National Health Insurance), the gap in the number of medical services between doctors and civil servants is increasing. The results of the study of the effect of incentives on work motivation are carried out by Ghazanfar et al., (2011), which stated that satisfaction with incentives can be a work motivation factor. Randy et al., (2012), showed 
Journal of Health Policy and Management (2016), 1(2): 61-71

https://doi.org/10.26911/thejhpm.2016.01.02.01

that incentives can increase employee work motivation.

Work period is the only characteristic of nurses that significantly influences the quality of medical record documents. Supratti and Ashriady (2016), stated that documentation of good and quality nursing care processes must be accurate, complete, and in accordance with standards. If nursing activities are not accurately and completely documented, it is difficult to prove that nursing interventions have been carried out correctly. The results of thestudy showed that the nursing sheet documents were mostly (94.6\%) in the inaccurate category because of a lack of work motivation and nurse experience.

Nurses at Dr. Moewardi hospital with tenure of $\geq 5$ years has a better quality medical record document $(8.80 \%)$ than nurses with tenure $<5$ years $(36.50 \%)$. Farida (2011), argued that the longer a person works, the more skilled and faster they will be in completing their tasks. Likewise the opinion of Fardiansyah (2014), which stated that the less long the working period is, the easier it is for someone to experience stress. A person will not experience stress if he is able to make a healthy response to stress as a form of balance improvement in the environment system from inside and outside or called as the adaptation process. The thing that really influences the stress response is coping mechanism or length of work.

The results of this study also indicate that the characteristics of personnel coding are the most dominant variable and directly influence the quality of the diagnosis code. Variables that were proven to have a significant effect were age, years of service, and training. Accuracy in giving a diagnosis coding is something that must be considered by medical recording personnel, the accuracy of data diagnosis is very important in the field of clinical data management, cost collection, along with other matters relating to care and health services (Hatta, 2013).

According to Hsia et al. (2009), $61.70 \%$ of coding errors that occur in health services are spread to doctors and hospital administration officers in charge of handling coding activities. This error is mostly done by coding personnel who are unable to understand code selection for more complex diseases. Based on the study, it can be seen that the coding of personnel in conducting coding must really understand the disease suffered by the patient and then determine the diagnosis coding to minimize the error of the coding produced. Something similar was also stated by Berger et al., (2015), of the 4 types of error diagnosis coding, all errors were caused by coding personnel and there was only one type of error caused by a doctor.

Most coding personnel who are $<40$ years of age are $87.50 \%$. This is also in accordance with Rivai (2003), which stated that a person at a young age is more productive than in old age. Dariyo (2003), stated the same thing that productive age is young adulthood, which is $20-40$ years.

The results of this study are in accordance with the study of Farzandipour et al., (2010), which stated that lack of experience in personnel coding can cause inaccuracies in diagnosis codes $(\mathrm{p}<0.001)$. A study by Rahayu et al. (2011) also showed that one of the factors that caused the inaccuracy of the diagnosis coding is because the new coding personnel had experience working in the codification section just for one year.

Coding personnel who had attended training $\geq 5$ times had better diagnosis coding quality (89.80\%) than $\geq 5$ with training $<5$ times (45.10\%). Ivancevich et al., (2008), suggested that training is a systematic process to change the work behavior of a person / group of employees in an 
effort to improve organizational performance.

Training is related to the skills and abilities needed for the work done. The results of this study are in accordance with the study of Rahayu et al., (2011), which stated that one of the factors that caused the inaccuracy of the diagnosis coding was because the coding personnel had never attended codification training. In addition, the study of Abiayasa et al. (2012) showed that the accuracy of the diagnosis coding is not only influenced by the writing of specific primary diagnoses but also influenced by the activeness factor of coding in finding specific diagnosis information so that codification training with ICD-10 has very important role.

Most of the quality of the diagnosis coding in Dr. Moewardi hospital is good, as many as 152 (60.80\%), while the diagnosis coding that is not good as many as 98 (39.20\%). The quality of poor medical record documents is $86(34.40 \%)$, where the most common causative factor is due to incomplete medical record documents. The quality of a good medical record document also has a better quality diagnostic coding (73.80\%) compared to the quality of an inadequate medical record document (36$.00 \%)$.

Completeness of writing medical information on each medical record form has an important role in determining the right code through a diagnosis set by the doctor. The results of the study by Rohman et al., (2011), stated that one of the factors that influence the accuracy of the diagnosis coding is medical information. Medical information in question is a diagnosis.

A study by Astuti et al. (2007), also discussed that accurate codes are obtained, one of which is by paying attention to supporting information or other information that affects the diagnosis coding. Pujihas- tuti and Sudra (2014), stated that there is a significant relationship between completeness of document record information medical with the accuracy of disease diagnosis coding in inpatient medical record documents ( $\mathrm{p}<\mathrm{o.001)}$.

The results of this study are also in accordance with the study of Farzandipour et al., (2010), which stated that the medical record documentation is more complete about topography $(\mathrm{p}=0.204)$, subtypes $(\mathrm{p}=$ $0.708)$, and etiology $(\mathrm{p}<0.001)$ disease can affect the accuracy of the diagnosis coding. Cheng et al. (2009), also showed that the most significant factor underlying the error of diagnosis coding and changes in DRGs is the low quality of medical record documentation.

\section{REFERENCE}

Abiyasa MT, Ernawati D, Kresnowati L (2012). Hubunganantaraspesifitaspenulisan diagnosis terhadap akurasi kode pada RM 1 dokumen rawat inap rumah sakit Bhayangkara Semarang (The relationship between the specificity of the diagnosis to the accuracy of the code in the record 1 medical documents Bhayangkara Hospital in Semarang). Jurnal Visikes. 11(2): 99104. Retrieved from http://publikasi.dinus.ac.id/index.php/visikes/article /view/671

Arifianto E, Kresnowati L, Ernawati D (2011). Keakuratan kode diagnosa utama dokumen rekam medis pada kasus partus dengan sectio cesarean di Rumah Sakit Panti Wilasa Citarum (Accuracy of the main diagnostic code of medical record in the case of Partus with Sectio cesarean at Panti Wilasa Citarum Hospital). Jurnal Visikes. 10(2): 84-88. Retrieved from http://publikasi.dinus.ac.id/index.php/visikes/ article/view/688 
Astuti RD, Riyoko, Lena D (2007). Tinjauan akurasi kode diagnosis utama pasien rawat inap berdasarkan ICD-10 Bangsal Dahlia di RSUD SukoharjoTriwulan IV Tahun 2007 (Review accuracy of key diagnosis code of inpatient based on ICD-10 Bangsal Dahlia at RSUD Sukoharjo quarter IV year 2007). Jurnal Rekam Medis. 2(1): 25-30. Retrieved from https://www.ejurnal.stikesmhk.ac.id/index.php/rm/article/view/26

Berger RP, Parks S, Fromkin J, Rubin P, Pecora PJ (2015). Assessing the accuracy of the international classification of diseases codes to identify abusive head trauma: A feasibility study. Inj Prev. 21(0): 133-137. doi 10.1136/injuryprev-2013-040924

Cheng P, Gilchrist A, Robinson KM, Paul L (2009). The risk and consequences of clinical miscoding due to inadequate medical documentation: A case study of the impact on health services funding. Health Inf Manag. 38(1): 35-46. doi 10.1177/183335830903800105

Cummings E, Maher R, Showell CM, Croft T, Tolman J, Vickers J, Stirling C, Robinson A, Turner P (2011). Hospital coding of dementia: Is it accurate. Health Inf Manag. 40(3): 5-11. doi: 10.1177/183335831104000301

Dalal S, Roy B (2009). Reliability of clinical coding of hip facture surgery: implications for payment by results. Injury. 40 (1): 738-741. doi: 10.1016/j.injury.2008.11.018

Dariyo A (2003). Psikologi perkembangan dewasa muda. Jakarta: PT. Gramedia Widiasarana Indonesia.

Djafar F, Pasinringi S, Sudirman I (2011). Faktor insentif, kepemimpinan, kondisi lingkungan kerja dan kesempatan promosi yang berpengaruh terhadap kepuasan kerja dokter spesialis di RS-
UP Dr. Wahidin Sudirohusodo (Factors such as incentives, leadership, environmental conditions and promotional opportunities that affect the job satisfaction of a specialist at the RSUP Dr. Wahidin Sudirohusodo). Public Health Journal, 14(5): 60-64. Retrieved from http://pasca.unhas.ac.id/jurnal/files/cb9042ccfe7aoce18a5cf3 9e82e3e617.pdf

Fardiansyah A (2014). Analisis hubungan beban kerja dan lama masa kerja denganstres pada perawat di Puskesmas Bloto, Kota Mojokerto (Analysis of workload and long working time with stress on the nurse in Bloto Puskesmas, Mojokerto). Jurnal Medica Majapahit, 6(2): 96-107. Retrieved from https://www.semanticscholar.org/paper/ANALISIS-HUBUNGAN-BEBAN-KERJA-DAN-LAMA-MASAKERJA-Fardiansyah/ea3d41d8do77be2db5624c18a313a59d53e5db72

Farida (2011). Kepemimpinan efektif dan motivasi kerja dalam penerapan komunikasi terapeutik perawat (Effective leadership and work motivation in the application of nurse therapeutic communication). Jurnal Ners. 6(1); 31-41. Retrieved from https://e-journal.unair.ac.id/JNERS/article/view/3 963

Farzandipour M, Sheikhtaheri A, Sadoughi F (2010). Effective factors on accuracy of principal diagnosis coding based on international classification of diseases, the 10th revision (ICD-10). International Journal of Information Management. 30: 78-84.https://doi.org/10.1016/j.ijinfomgt.2009.07.002

Ghazanfar F, Chuanmin S, Khan MM, Bashir M (2011). A study of relationship between satisfaction with compensation and work motivation. International Journal of Business and So- 
cial Science. 2(1): 120-131. Retrieved from https://pdfs.semanticscholar.org/9b66/5e99595bd24b53b7b391dc27 fbegb45ca7b2.pdf.

Hatta G (2013). Pedoman manajemen informasi kesehatan di sarana pelayanan kesehatan (Health information management guidelines in health care facilities). Jakarta: Universitas Indonesia Press.

Hsia DC, Krushat WM, Fagan AB, Tebutt JA, Kusserow RP (2009). Accuracy of diagnostic coding for medicare patients under the prospective-payment system. N Engl J Med. 318: 352-355. doi: 10.1056/NEJM198802113180604

Hurriyati R (2005). Bauran pemasaran dan loyalitas konsumen (Marketing mix and customer loyalty). Bandung: Alfabeta.

Ifalahma D (2013). Hubungan pengetahuan coder dengan keakuratan kode diagnosis pasien rawat inap jaminan kesehatan masyarakat berdasarkanICD-10 di RSUD Simo, Boyolali. Jurnal INFOKES. 3(2): 14-26.

Karimah RN, Setiawan D, Nurmalia PS (2016). Analisis ketepatan kode diagnosis penyakit gastroenteritis acute berdasarkan dokumen rekam medis di Rumah Sakit Balung, Jember (Analysis of correctness code diagnosis of gastroenteritis acute based on medical record in hospital Balung, Jember). Journalof Agromedicine and Medical Sciences. 2(2): 12-17. Retrieved from https://jurnal.unej.ac.id/index.php/J AMS/article/download/2775/2236/

Kemenkes RI (2006). Pedoman pengelolaan rekam medis rumah sakit Indonesia (Indonesian hospital medical Record management guidelines). Jakarta: Kemenkes RI. Retriefed from https://dokumen.tips/documents/pedom an-pengelolaan-rekam-medis-rumahsakit-di-indonesia.html

Lihawa C, Noermijati, Al R (2016). Pengaruh motivasi kerja terhadap kinerja dokter dalam kelengkapan pengisian rekam medis dengan di moderasi karakteristik individu: Studi di Rumah Sakit Islam Unisma Malang (Effect of working motivation on doctor's performance in completeness of medical record filling with moderated individual characteristics: study at Unisma Islamic Hospital Malang). Jurnal Aplikasi Manajemen.14(2):300-308. Retrieved from https://jurnaljam.ub.ac.id/index.php/jam/article/view/890.

Muljani N (2012). Kompensasi sebagai motivator untuk meningkatkan kinerja karyawan (Compensation as a motivator to improve employee performance). Jurnal Manajemen dan Kewirausahaan. 4(2): 13-20. Retrieved from http://jurnalmanajemen.petra.ac.id/index.php/man/article/download/15627/15619.

Pujihastuti A, Sudra RI (2014). Hubungan kelengkapan informasi dengan keakuratan kode diagnosis dan tindakan pada dokumen rekam medis rawat inap (Completeness of information with the accuracy of diagnostic codes and actions on inpatient medical record documents). JurnalManajemenInformasi Kesehatan Indonesia. 3(1): 6064. Retrieved from https://www.jmiki.aptirmik.or.id/index.php/jmiki/art icle/viewFile/25/11.

Rahayu H, Ernawati D, Kresnowati L (2011). Akurasi kode diagnosis utama pada RM 1 dokumen rekam medis ruang karmel dan karakteristik petugas kodingrawat inap Rumah Sakit Mardi Rahayu Kudus periode Desember 2009 (Accuracy of key diagnostic codes on medical record 1 medical re- 
cord document and the characteristics of hospitalization officers of the hospital Mardi Rahayu Kudus period, December 2009). Jurnal Visikes. 10(1): 1-5. Retrieved from http://publikasi.dinus.ac.id/index.php/visikes/article/ view/679

Randy KC, Vivienne WML, Tang TLP (2012). Retaining and motivating employees compensation preferences in Hong Kong and China. Personnel Review. 31(4): 402-431. Retrieved from https://www.emerald.com/insight/co ntent/doi/10.1108/00483480210430 346/full/html

Rivai V (2003). Kepemimpinan dan perila$\mathrm{ku}$ organisasi (organizational leadership and behavior). Jakarta: Raja GrafindoPersada.

Rohman H, Hariyono W, Rosyidah (2011). Kebijakan pengisian diagnosis utama dan keakuratan kode diagnosis pada rekam medis di Rumah Sakit PKU Muhammadiyah Yogyakarta (Main diagnosis policy and accuracy of the diagnostic code in the medical record at the hospital PKU Muhammadiyah Yogyakarta). Jurnal Kesmas. 5(2): 162-232. Retrieved from https://media.neliti.com/media/publications/25005-ID-kebijakan-pengisian-diagnosis-utama-dan-keakuratan-kodediagnosis-pada-rekam-med.pdf

Rustiana ER, Cahyati WH (2012). Stress kerja dengan pemilihan strategi coping (working stress with coping strategy selection). Jurnal Kesmas. 7(2): 149-155. Retrieved from https://journal.unnes.ac.id/nju/index.php/kemas/article/view/2811

Sarwastutik (2013). Tinjauan keakuratan kode diagnosis pada dokumen rekam medis pasien rawat inap dengan kondisi utama typhoid fever berdasarkan ICD-X di RSU PKU Muhammadiyah
Delanggu (Accurate review of diagnostic codes on hospitalized medical record documents with the main condition of typhoid fever based on ICD$\mathrm{X}$ at RSU PKU Muhammadiyah Delanggu). Jurnal Infokes. 3(2): 8-13. Retrieved from https://www.semanticscholar.org/paper/TINJAUAN-KEAKURATAN-KODE-DIAGNOSIS-PADA-DOKUMEN-ICD-Sarwastutik/do7a1ce949ed94aa53659be8cdcaea255d 79e3b9

Seruni FDA, Sugiarsi S (2015). Problem solving cycle swot keakuratan kode diagnosis kasus obstetri pada lembar masuk dan keluar (RM 1a) pasien rawat inap di RSUD Dr. Sayidiman Magetan (Problem solving cycle SWO$\mathrm{T}$ accuracy code Diagnosis of obstetric cases on the entry and exit sheet (RM 1a) inpatient in hospital Dr. Sayidiman Magetan). Jurnal Manajemen Informasi Kesehatan Indonesia. 3(2): 513. Retrieved from https://jmiki.aptirmik.or.id/index.php/jmiki/article/ view/78.

Siagian (2008). Manajemen sumberdaya manusia (Human resource management). Jakarta: Bumi Aksara.

Sudra RI, Pujihastuti A (2016). Pengaruh penulisan dianosis danpengetahuan petugas rekam medis tentangterminologi medis terhadapkeakuratankode diagnosis (The influence of writing diagnosis and the knowledge of medical record officers on medical terminology to the accuracy of the diagnostic code). Jurnal Manajemen Informasi Kesehatan Indonesia. 4(1): 67-72. Retrieved from http://jmiki.aptirmik.or.id/index.php/jmiki/article/viewFil e/99/82

Sugiyanto $Z$ (2006). Analisis perilaku dokter dalam mengisi kelengkapan data rekam medis lembar resume rawat 
inap di RS Ungaran (Analysis of doctor behaviour in filling the completeness of medical record of hospitalisation resume sheet at Ungaran Hospital). Jurnal Kesehatan, 12(3): 115159. Retrieved from http://eprints.undip.ac.id/15959/

Suma'mur S (2014). Kesehatan kerja dalam perspektif hiperkes dan keselamatan kerja (Occupational health in the perspective of transmigration and occupational safety). Jakarta: Erlangga.

Supratti, Ashriady (2016). Pendokumentasian standar asuhan keperawatan di rumah sakit umum daerah Mamuju, Indonesia (Standard documentation for nursing care at public hospitals in the area of Mamuju, Indonesia). Jurnal Kesehatan Manarang. 2(1): 43-50. Retrieved from http://jurnal.poltekkesmamuju.ac.id/index.php/m/articl e/download/13/12/

Thigpen JL, Pharm, Dillon C, Forster KB, Henault L, Quinn EK, Tripodis Y, et al. (2015). Validity of international classification of disease codes to identify ischemic stroke and intracranial hemorrhage among individuals with associated diagnosis of atrial fibrillation. Circ Cardiovasc Qual Outcomes. 8(1): 8-14. doi: 10.1161/CIRCOUTCOMES.113.000371.

WHO (2010). International statistical classification of diseases and related health problems tenth revision volume 1, 2 and 3. Geneva. Retrieved from https://apps.who.int/iris/handle/10665/246208

Yulianto H, Santoso E (2015). Persepsi dan ekspektasi dokter terhadap jasa medis di RS PKU Muhammadiyah Nanggulan (Doctor's perception and expectation of medical services at PKU Muhammadiyah Nanggulan hospital). Jurnal Kesehatan. 33(1): 147152. Retrieved from https://media.neliti.com/media/publications/114878-IDpersepsi-dan-ekspektasi-dokter-terhadap.pdf 